\title{
Disseminated Histoplasmosis in a Patient With Multiple Sclerosis Treated With Fingolimod
}

Aleksandra A. Abrahamowicz, MD, * Eric J. Chow, MD, MS, MPH, * Daniel D. Child, MD, PhD, Alexander Dao, MD, Elizabeth D. Morrison, MD, Sharon K. Gill, MD, David M. Rogers, MD, and Kanishka Garvin, MD

Neurol Neuroimmunol Neuroinflamm 2021;8:e966. doi:10.1212/NXI.0000000000000966

Histoplasma capsulatum is an endemic dimorphic fungus found in the central and eastern parts of the United States, leading to infection when conidia from soil or dust contaminated with bird or bat droppings are inhaled. ${ }^{1}$ Histoplasmosis can result in disseminated infection, with the gastrointestinal tract being a common site. ${ }^{2}$ We describe a case of histoplasmosis in a patient with multiple sclerosis (MS) on immunomodulatory therapy presenting with gastrointestinal disease.

\section{Case}

The patient is a 46-year-old man with relapsing-remitting MS who presented with 3 weeks of fevers, night sweats, and unintentional 20-lbs weight loss without any respiratory symptoms. He described nonbloody stool caliber changes. Outpatient laboratory findings include an elevated alkaline phosphatase $540 \mathrm{U} / \mathrm{L}$ (reference range 45-129) that was normal 5 months previous and a positive fecal immunochemical test. He was originally diagnosed with MS in December 2017 after an acute onset left-sided hemisensory loss and an MRI showing involvement of brain and cervical spine with a negative infectious and autoimmune workup. Since his diagnosis in 2017, he had been well controlled on fingolimod, a sphingosine-1-phosphate receptor agonist, with only mild sensory deficits in his left hand and an expanded disability status scale of $1 . \mathrm{He}$ has not used other immunosuppressive medications. He is a military veteran with deployments to Afghanistan, Iraq, and countries in Africa and the Pacific Rim with no travel since 2017. He had no other high-risk behaviors or exposures.

At admission, he was afebrile with normal vital signs and only demonstrated moderate right upper quadrant abdominal tenderness. He had a mildly elevated alanine transaminase (ALT) 69 U/L (reference: 0-37) and aspartate aminotransferase (AST) $57 \mathrm{U} / \mathrm{L}$ (reference: 0-39). Other laboratory tests included alkaline phosphatase at $607 \mathrm{U} / \mathrm{L}$, total bilirubin $1.5 \mathrm{mg} / \mathrm{dL}$ (reference 0.1-1.0), and white blood cell count of $4.3 \mathrm{~K} / \mathrm{uL}$ (reference 4.3-10). CT and magnetic resonance cholangiopancreatography revealed gallbladder wall thickening and heterogeneous liver parenchyma.

He continued to experience nightly fevers up to $38.4^{\circ} \mathrm{C}$. Repeated blood cultures showed no bacterial growth. HIV and hepatitis tests were negative. A colonoscopy showed innumerable sessile lesions ranging from 3 to $8 \mathrm{~mm}$ in size (figure e-1, links.lww.com/NXI/A419), biopsies of which were sent to pathology. A liver biopsy was also obtained on hospital day 4 . Histopathologic evaluation of the colonic mucosa demonstrated marked lamina propria histiocytosis with severely disrupted crypt architecture. Individual histiocytes had a high burden of intracellular organisms with thick, ovoid cell walls, consistent with a fungal species (figure 1A). The liver core biopsies contained multiple caseating granulomas (figure $1 \mathrm{~B}$ ) replete with yeast-

\author{
Correspondence \\ Dr. Chow \\ ejchow@uw.edu.
}

\footnotetext{
*These authors contributed equally to this work.

From the Department of Medicine (A.A.A., S.K.G.), University of Washington; Division of Allergy and Infectious Diseases (E.J.C., K.G.), Department of Medicine, University of Washington; Department of Laboratory Medicine and Pathology (D.D.C.), University of Washington; Division of Gastroenterology (A.D.), Department of Medicine, University of Washington; Gastroenterology (E.D.M.), VA Puget Sound Health Care System; General Medicine Service (S.K.G.), VA Puget Sound Health Care System; Pathology and Laboratory Medicine Service (D.M.R.), VA Puget Sound Health Care System; and Allergy and Infectious Diseases (K.G.), VA Puget Sound Health Care System, Seattle, WA. 


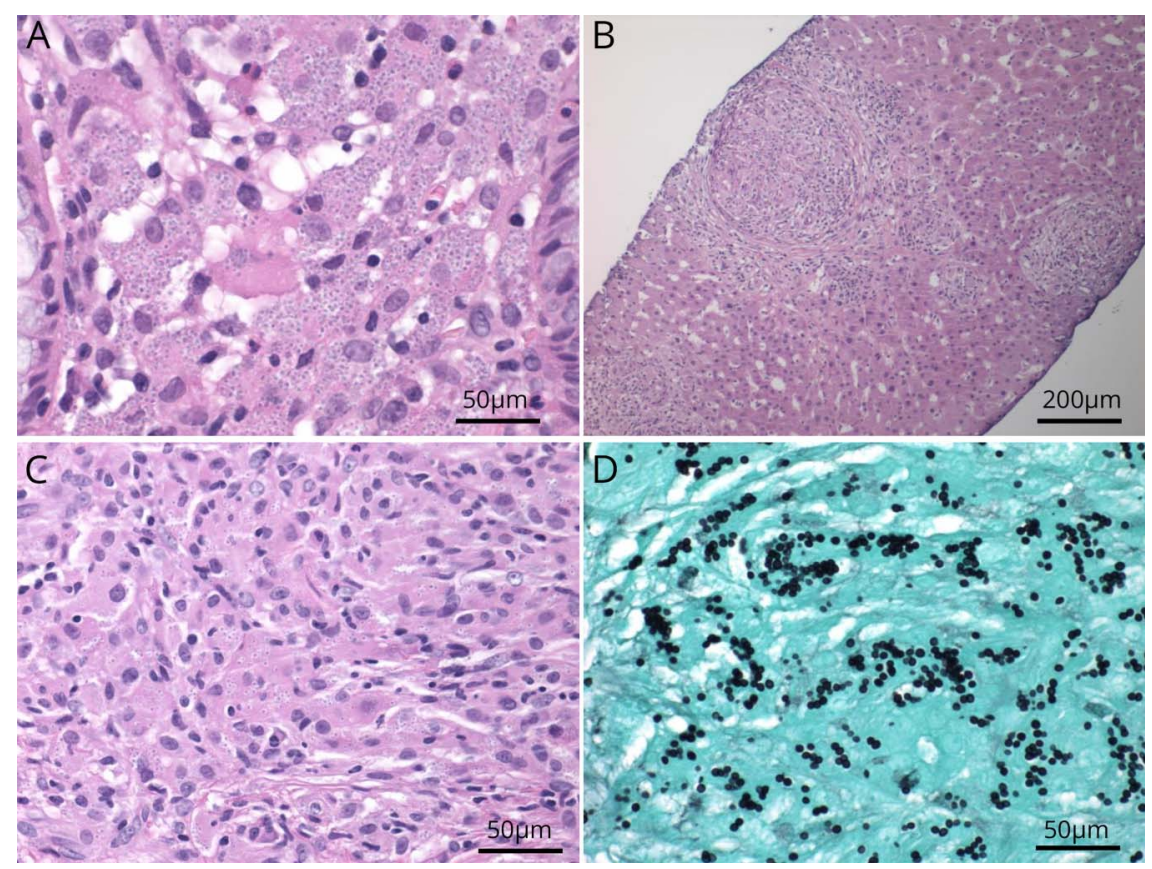

(A) Intracellular $H$. capsulatum in colonic submucosa. (B) Caseating granulomas in liver core biopsy. (C) H. capsulatum in hepatic granulomas. (D) GMS-stained sections of hepatic granulomas highlighting $H$. capsulatum organisms. GMS = Grocott methenamine silver. laden histiocytes identical to those observed in the colon (figure 1C). Grocott methenamine silver stain highlighted the cell walls of the intracellular species within the hepatic granulomas (figure 1D). Chronic inflammatory infiltrate was present in biopsies from both sites, but neutrophilic and eosinophilic inflammation was absent. Molecular testing diagnosed H. capsulatum. On further questioning on hospital day 7 , the patient noted that he was renovating a barn in Michigan in which he had encountered dead bats and rodents.

The patient was treated with liposomal amphotericin B at $4 \mathrm{mg} /$ $\mathrm{kg}$ daily. Because of increasing alkaline phosphatase and increasing AST and ALT, itraconazole $200 \mathrm{mg}$ twice daily replacing amphotericin on day 6 of therapy was administered with plans to complete at least 1 year of therapy.

\section{Discussion}

Our case highlights the morbidity associated with delayed recognition of disseminated histoplasmosis in an immunocompromised patient. Histoplasmosis commonly causes fever, fatigue, and weight loss and a diagnosis should be considered in individuals with risk factors. This patient's MS had been treated with fingolimod which leads to lymphocyte sequestration in lymph nodes. ${ }^{3}$ Fingolimod has been associated with fungal infections including one patient with primary cutaneous histoplasmosis. ${ }^{4}$

Gastrointestinal histoplasmosis without pulmonary symptoms is rare and usually presents with abdominal pain, melena, diarrhea, and bowel obstruction. ${ }^{2}$ Cases of $H$. capsulatum with granulomatous hepatitis and associated cholestasis include findings of jaundice and elevated alkaline phosphatase. ${ }^{5,6}$ Rapid diagnosis of histoplasmosis can be achieved by serum and urine enzyme immunoassay antigen testing. Immunodiffusion and complement fixation serologic testing are also available, but they may be less sensitive in immunocompromised individuals. The gold standard for identification of $H$. capsulatum is by isolation of organisms through culture or microbiologic stains. ${ }^{1}$

Treatment for disseminated histoplasmosis should be initiated promptly because the disease is almost entirely fatal within 3 months. ${ }^{1}$ Liposomal amphotericin B is recommended as first-line therapy in those with severe disease with a transition to intraconazole after 1-2 weeks of amphotericin to complete 12 months of therapy. ${ }^{7}$ For immunocompromised patients, lifelong suppressive antifungal therapy may be required if immunosuppression is expected to persist. ${ }^{7}$

This case highlights the importance of considering histoplasmosis in patients with MS on immunomodulatory therapy and exposure risk factors because gastrointestinal histoplasmosis can mimic malignancy in the absence of pulmonary disease. Prompt diagnosis and early treatment are vital because disseminated histoplasmosis is ultimately fatal without treatment.

\section{Study Funding}

No targeted funding reported.

\section{Disclosure}

Disclosures available: Neurology.org/NN.

\section{Publication History}

Received by Neurology: Neuroimmunology \& Neuroinflammation November 24, 2020. Accepted in final form January 8, 2021. 
Appendix Authors

\begin{tabular}{|c|c|c|}
\hline Name & Location & Contribution \\
\hline $\begin{array}{l}\text { Aleksandra A. } \\
\text { Abrahamowicz, } \\
\text { MD }\end{array}$ & $\begin{array}{l}\text { Department of Medicine, } \\
\text { University of } \\
\text { Washington, Seattle }\end{array}$ & $\begin{array}{l}\text { Drafting/revision of the } \\
\text { manuscript for content, } \\
\text { including medical writing } \\
\text { for content, and major } \\
\text { role in the acquisition of } \\
\text { data }\end{array}$ \\
\hline $\begin{array}{l}\text { Eric J. Chow, } \\
\text { MD, MS, MPH }\end{array}$ & $\begin{array}{l}\text { Division of Allergy and } \\
\text { Infectious Diseases, } \\
\text { Department of Medicine, } \\
\text { University of } \\
\text { Washington, Seattle }\end{array}$ & $\begin{array}{l}\text { Drafting/revision of the } \\
\text { manuscript for content, } \\
\text { including medical writing } \\
\text { for content; major role in } \\
\text { the acquisition of data; } \\
\text { and study concept or } \\
\text { design }\end{array}$ \\
\hline $\begin{array}{l}\text { Daniel D. Child, } \\
\text { MD, PhD }\end{array}$ & $\begin{array}{l}\text { Department of } \\
\text { Laboratory Medicine and } \\
\text { Pathology, University of } \\
\text { Washington, Seattle }\end{array}$ & $\begin{array}{l}\text { Drafting/revision of the } \\
\text { manuscript for content, } \\
\text { including medical writing } \\
\text { for content; major role in } \\
\text { the acquisition of data; and } \\
\text { study concept or design }\end{array}$ \\
\hline $\begin{array}{l}\text { Alexander Dao, } \\
\text { MD }\end{array}$ & $\begin{array}{l}\text { Division of } \\
\text { Gastroenterology, } \\
\text { Department of Medicine, } \\
\text { University of } \\
\text { Washington, Seattle }\end{array}$ & $\begin{array}{l}\text { Drafting/revision of the } \\
\text { manuscript for content, } \\
\text { including medical writing } \\
\text { for content }\end{array}$ \\
\hline $\begin{array}{l}\text { Elizabeth D. } \\
\text { Morrison, MD }\end{array}$ & $\begin{array}{l}\text { Gastroenterology, VA } \\
\text { Puget Sound Health Care } \\
\text { System, Seattle, WA }\end{array}$ & $\begin{array}{l}\text { Drafting/revision of the } \\
\text { manuscript for content, } \\
\text { including medical writing } \\
\text { for content }\end{array}$ \\
\hline $\begin{array}{l}\text { Sharon K. Gill, } \\
\text { MD }\end{array}$ & $\begin{array}{l}\text { General Medicine } \\
\text { Service, VA Puget Sound } \\
\text { Health Care System, } \\
\text { Seattle, WA }\end{array}$ & $\begin{array}{l}\text { Drafting/revision of the } \\
\text { manuscript for content, } \\
\text { including medical writing } \\
\text { for content and major role } \\
\text { in the acquisition of data }\end{array}$ \\
\hline
\end{tabular}

Appendix (continued)

\begin{tabular}{lll}
\hline Name & Location & Contribution \\
\hline $\begin{array}{l}\text { David M. } \\
\text { Rogers, MD }\end{array}$ & $\begin{array}{l}\text { Pathology and } \\
\text { Laboratory Medicine } \\
\text { Service, VA Puget Sound } \\
\text { Health Care System, } \\
\text { Seattle, WA }\end{array}$ & $\begin{array}{l}\text { Drafting/revision of the } \\
\text { manuscript for content, } \\
\text { including medical writing } \\
\text { for content }\end{array}$ \\
\hline $\begin{array}{l}\text { Kanishka } \\
\text { Garvin, MD }\end{array}$ & $\begin{array}{ll}\text { Allergy and Infectious } \\
\text { Diseases, VA Puget } \\
\text { Sound Health Care } \\
\text { System, Seattle, WA }\end{array}$ & $\begin{array}{l}\text { Drafting/revision of the } \\
\text { manuscript for content, } \\
\text { including medical writing } \\
\text { for content; major role in } \\
\text { the acquisition of data; } \\
\text { and study concept or } \\
\text { design }\end{array}$ \\
& & \\
& &
\end{tabular}

\section{References}

1. Kauffman CA. Histoplasmosis: a clinical and laboratory update. Clin Microbiol Rev 2007;20:115-132.

2. Kahi CJ, Wheat LJ, Allen SD, Sarosi GA. Gastrointestinal histoplasmosis. Am J Gastroenterol 2005;100:220-231.

3. Thomas K, Proschmann U, Ziemssen T. Fingolimod hydrochloride for the treatment of relapsing remitting multiple sclerosis. Expert Opin Pharmacother 2017;18: $1649-1660$

4. Veillet-Lemay GM, Sawchuk MA, Kanigsberg ND. Primary cutaneous Histoplasma capsulatum infection in a patient treated with fingolimod: a case report. J Cutan Med Surg 2017;21:553-555

5. Rihana NA, Kandula M, Velez A, Dahal K, O’Neill EB. Histoplasmosis presenting as granulomatous hepatitis: case report and review of the literature. Case Rep Med 2014; 2014:879535.

6. van Welzen BJ, van Erpecum KJ, Haas PJ, ten Kate FJ, Mudrikova T. Severe cholestasis due to disseminated histoplasmosis under adalimumab-containing immunosuppressive therapy. Clin Res Hepatol Gastroenterol 2013;37: e105-107.

7. Wheat LJ, Freifeld AG, Kleiman MB, et al. Clinical practice guidelines for the management of patients with histoplasmosis: 2007 update by the Infectious Diseases Society of America. Clin Infect Dis 2007;45:807-825. 


\title{
Neurology \\ Neuroimmunology \& Neuroinflammation
}

\author{
Disseminated Histoplasmosis in a Patient With Multiple Sclerosis Treated With \\ Fingolimod \\ Aleksandra A. Abrahamowicz, Eric J. Chow, Daniel D. Child, et al. \\ Neurol Neuroimmunol Neuroinflamm 2021;8; \\ DOI 10.1212/NXI.0000000000000966
}

This information is current as of February 18, 2021

Updated Information \&

Services

References

Subspecialty Collections

Permissions \& Licensing

Reprints including high resolution figures, can be found at:

http://nn.neurology.org/content/8/3/e966.full.html

This article cites 7 articles, 1 of which you can access for free at: http://nn.neurology.org/content/8/3/e966.full.html\#\#ref-list-1

This article, along with others on similar topics, appears in the following collection(s):

All Immunology

http://nn.neurology.org//cgi/collection/all_immunology

Fungal infections

http://nn.neurology.org//cgi/collection/fungal_infections

Multiple sclerosis

http://nn.neurology.org//cgi/collection/multiple_sclerosis

Information about reproducing this article in parts (figures,tables) or in its entirety can be found online at:

http://nn.neurology.org/misc/about.xhtml\#permissions

Information about ordering reprints can be found online:

http://nn.neurology.org/misc/addir.xhtml\#reprintsus

Neurol Neuroimmunol Neuroinflamm is an official journal of the American Academy of Neurology.

Published since April 2014, it is an open-access, online-only, continuous publication journal. Copyright

Copyright (C) 2021 The Author(s). Published by Wolters Kluwer Health, Inc. on behalf of the American

Academy of Neurology.. All rights reserved. Online ISSN: 2332-7812.

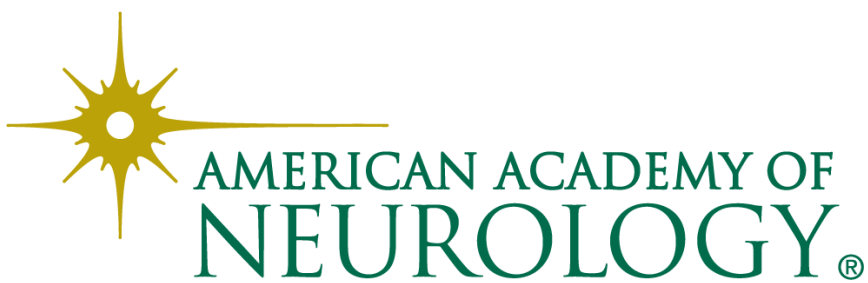

